\title{
EXPLORING THE ROLE OF THE TYPE OF SERVICE ENCOUNTER IN INTERNET SHOPPING
}

\author{
Ramón Barrera Barrera* \\ University of Seville \\ Antonio Navarro García \\ University of Seville \\ Borja Sanz Altamira \\ University of Seville
}

\begin{abstract}
In the context of electronic commerce B2C, two different service encounters can take place: 1) service encounters without incidents during which customers get the service for themselves and without the presence of employees and 2) service encounters with incidents with interpersonal and non-interpersonal interactions. The model proposed is based on the service qualitysatisfaction-loyalty intention chain and it is evaluated through a sample of 718 online shoppers. The results obtained reflect that 1 ) the type of the service encounter has a moderating effect in these relationships. In this sense, the effects are stronger when incidents take place and are satisfactorily resolved; 2) regardless of the type of service encounter, reliability is the most important dimension in the assessing of a Website's service quality, followed by the recovery of the electronic service when the service encounter takes place with incidents; 3) furthermore, consumers who have had no incident during the service encounter perceive a greater service quality, show higher levels of satisfaction and loyalty intentions toward the Website than those who have had a problem during the service provision.
\end{abstract}

Keywords: Electronic Service Quality; Online Shopping Behavior; Satisfaction; Loyalty Intentions.

\section{INTRODUCTION}

Internet has revolutionized commerce and business (e.g., Hoffman and Novak, 1996) and one of the most significant indicators of this transformation has been the adoption of the online retail channel. Specifically, in the European Union, the proportion of individuals aged 16 to 74 having ordered goods or services for private use over the

\footnotetext{
"Corresponding Author: Management and Marketing Department, University of Seville, Ramón y Cajal, 1+3441018, Seville, Spain. Tel.: +34954554438 Email: rbarrera@us.es
} 
internet ("e-buyers") has continuously risen, from 30\% in 2007 to 53\% in 2015 (Eurostat, 2016). This volume of business generated by the B2C e-commerce accounts for $17 \%$ of the total turnover of companies with 10 or more persons employed. In addition, 73\% of households and 92\% of companies in the EU-28 are connected to the Web (Eurostat 2016). The face to face interpersonal interactions between sellers and customers has been replaced with technology-based Web interfaces. The management of these service encounters should be a priority for any organization with a presence on the Internet. This paper develops and tests a model that reflects the importance of service encounter in the service quality perceived by customers, their satisfaction and loyalty intentions.

Many researchers point out that to deliver a superior service quality is one of the key determinants of online retailers' success (Zeithaml, Parasuraman, and Malhotra, 2002) and it is a major driving force on the route to long-term success (Fassnacht and Koese, 2006). To set out which aspects must be evaluated in the service quality, many researchers have used the service encounter approach (Bitner, 1990; Bitner et al., 1990; etc.). Shostack (1985: p.243) defines the term service encounter as "a period of time during which a consumer directly interacts with a service". This definition encompasses all aspects of the service firm with which the consumer may interact, including its personnel, its physical facilities and other tangible elements, during a given period of time. This view of a service encounter is still valid in the online services context. In the evaluation of e-service quality, it is necessary to consider all the cues and encounters that occur before, during and after the transactions (Zeithaml et al., 2002). Specifically, two different service encounters can take place in the context of Internet: (1) service encounters with non-interpersonal interactions, during which customers get the service for themselves, without the presence of employees (service encounter without incidents) and (2) service encounters with interpersonal and non-interpersonal interactions. Generally, the interactions with a member of the organization take place when a customer needs to solve any problem or doubt that may arise during the service delivery (service encounter with incidents). On the other hand, previous studies have tried to basically answer three questions: 1) which dimensions underlie the e-service quality construct? 2) Which dimensions are more important in the perception of the quality of the services offered through Internet? And 3) what is the influence of the service quality offered by a Website on the online customer's satisfaction and loyalty? The originality of our work is that it answers these questions from two perspectives: service encounters without incidents versus service encounters with incidents. Moreover, our research analyzes if the perceived service quality, the satisfaction with the online shopping and the loyalty intentions differ from one situation to the other.

To achieve the objectives proposed, the article is structured as follows. First, we review the most relevant research to help us identify the dimensions of e-service quality. We describe the sample and measures used in the study. Then, we show the results of the 
empirical research. Finally, we discuss the conclusions and implications for management, the limitations and future research lines.

\section{THEORETICAL BACKGROUND}

Since the pioneering work of Zeithaml et al. (2002), the quality of online services has been explored in some depth. Parasuraman, Zeithaml, and Berry (1985) suggest that service quality is an abstract and elusive construct because of three features that are unique to services: the intangibility, heterogeneity and inseparability of production and consumption. The best-known approach for measuring service quality is the SERVQUAL model (Parasuraman, Zeithaml, and Berry, 1988). The original five dimensions of SERVQUAL are tangibles, reliability, responsiveness, assurance and empathy. Some academic researchers have extended the SERVQUAL dimensions to the online context (Kaynama and Black, 2000; Sánchez-Franco and Villarejo-Ramos, 2004). However, traditional theories and concepts about service quality cannot be directly applied to the online context due to the important differences between the two settings. First, the service quality literature is dominated by people-delivered services, while in online services, human-to-human interactions are substituted by customer-to-Website interactions (Parasuraman, Zeithaml, and Malhotra, 2005). Therefore, responsiveness and empathy dimensions can be evaluated only when the online customer contacts a member of the organization. Second, although reliability and security dimensions may be useful, tangibles are irrelevant as the customer only interacts with the Website. Third, new dimensions are relevant, such as Website design or information quality. Fourth, if the evaluation of the quality of a traditional service is going to depend especially on the personnel in charge of the service provision, the quality of the services which are offered through Internet are going to largely depend on the consumers themselves and their interaction with the Website (Fassnacht and Koese, 2006). Fifth, compared to the traditional quality of service, the e-service quality is an evaluation which is more cognitive than emotional (Zeithaml, Parasuraman, and Malhotra, 2000). In this way, these authors state that negative emotions such as annoyance and frustration are less strongly shown than in the quality of the traditional service, while positive feelings of affection or attachment which exist in traditional services do not appear in the Internet context.

Various conclusions can be inferred from reviewing the literature: (1) the e-service quality is a multidimensional construct (Zeithaml, Parasuraman, and Malhotra, 2000) whose measurement must gather the evaluation of the interaction with the Website, the evaluation carried out by the customer of the product or service received and, if any problem arises, how the Website of the online firm handles it (Collier and Bienstock, 2006). (2) There are basically two approaches when tackling the conceptualization and measurement of e-service quality (Table 1). The epicenter of the first approach is the technical characteristics of the Website (technical quality). They centered uniquely on 
the interaction that takes place between the customer and the Website. The main proposal of these measurement instruments is to generate information for the site designers, more than measuring the quality of the service which customers perceive (Parasuraman et al., 2005). This weakness is the main motive for the appearance of the second approach (service quality) which offers a more complete vision of the field of the e-service quality construct. The dimensions and the measurement instruments gather not only the technical aspects of the Website, but also how the customers perceive the quality of the product or service received and how their problems or doubts were solved during the service provision. (3) The researchers do not agree when identifying the dimensions of the quality of an electronic service. (4) Some authors propose scales in which problem solving does not appear (e.g., Liu, Du, and Tsai, 2009) or is evaluated for the whole sample (e.g., Wolfinbarger and Gilly, 2003). However, this last aspect must only be evaluated by those people who had problems during the transaction (Parasuraman et al., 2005; Collier and Bienstock, 2006).

If we set out from the conceptualization proposed by Collier and Bienstock (2006, p. 263), the domain of the service quality construct should gather the evaluation of the quality of the process of online interaction (technical aspects), the result of how the service or the product is delivered (result) and the way in which the service failures (if they occur) are managed (service recovery). The technical characteristics of the Website must consider: design, functionality and privacy. Secondly, the evaluation of the product or service delivery has been carried out with a single dimension generally called reliability. Thirdly, if we take as a reference the works of Parasuraman, Zeithaml and Malhotra (2005) and Collier and Bienstock (2006), the evaluation of the quality of the eservice recovery responds to two aspects: the possibility of getting into touch with the firm (access or contact), and the effectiveness of problem solving (usually called response capacity). These dimensions are herewith defined and explained.

Table 1: Electronic service quality scales in online purchasing

\begin{tabular}{|c|c|}
\hline \multicolumn{2}{|c|}{ Focus: Technical quality } \\
\hline Article & Dimensions \\
\hline Aladwani and Palvia (2002) & $\begin{array}{l}\text { Appearance; specific content; content quality; technical } \\
\text { adequacy }\end{array}$ \\
\hline $\begin{array}{l}\text { Duque-Oliva and Rodríquez-Romero } \\
\text { (2012) }\end{array}$ & Efficiency; performance; privacy; system; variety \\
\hline Liu and Arnett (2000) & $\begin{array}{l}\text { Information and service quality; system use; playfulness; } \\
\text { system design quality }\end{array}$ \\
\hline Liu, Du and Tsai (2009) & $\begin{array}{l}\text { Adequacy of information; appearance; usability; privacy; } \\
\text { security }\end{array}$ \\
\hline Loiacono, Watson, and Goodhue (2002) & $\begin{array}{l}\text { Ease of understanding; intuitive operation; information } \\
\text { quality; interactivity; trust; response time; visual appeal; } \\
\text { innovativeness; flow }\end{array}$ \\
\hline Ranganathan and Ganapathy (2002) & Information content; design; security; privacy \\
\hline Sabiote, Frías, and Castañeda (2012) & $\begin{array}{l}\text { Ease of use; availability; efficacy; privacy; relevant } \\
\text { information; }\end{array}$ \\
\hline
\end{tabular}


Table 1: Electronic service quality scales in online purchasing (con’t)

\begin{tabular}{|c|c|}
\hline \multicolumn{2}{|c|}{ Focus: Technical quality } \\
\hline Article & Dimensions \\
\hline $\begin{array}{l}\text { Sanchez-Franco and Villarejo-Ramos } \\
(2004)\end{array}$ & $\begin{array}{l}\text { Assurance; tangibles; reliability; empathy, ease of use, } \\
\text { enjoyment; responsiveness }\end{array}$ \\
\hline San Martín and Jiménez (2011) & Privacy and security policies; warranty; service quality \\
\hline Yoo and Donthu (2001) & Ease of use; design; speed; security \\
\hline \multicolumn{2}{|c|}{ Focus: Electronic Service quality } \\
\hline Article & Dimensions \\
\hline Barrutia and Gilsanz (2012) & $\begin{array}{l}\text { Process quality: efficiency; system availability; design; } \\
\text { Information and Outcome quality }\end{array}$ \\
\hline Bauer, Falk, and Hammerschmidt (2005) & $\begin{array}{l}\text { Functionality / design; enjoyment; process; reliability; } \\
\text { responsiveness }\end{array}$ \\
\hline Collier and Bienstock (2006) & $\begin{array}{l}\text { Process dimension: functionality; information; accuracy; } \\
\text { design; privacy; ease of use; Outcome dimension: order } \\
\text { accuracy; order } \\
\text { condition; timeliness; Recovery dimension: interactive } \\
\text { fairness; procedural fairness; outcome fairness }\end{array}$ \\
\hline Fassnacht and Koese (2006) & $\begin{array}{l}\text { Quality of the environment: graphics quality, clear } \\
\text { presentation, quality of delivery: attractive assortment, quality } \\
\text { of information, ease of use, technical quality, outcome quality: } \\
\text { reliability, functional benefit; emotional benefit; }\end{array}$ \\
\hline Ho and Lee (2007) & $\begin{array}{l}\text { Information quality; security; functionality; customer } \\
\text { relationships; responsiveness }\end{array}$ \\
\hline Janda, Trocchia, and Gwinner (2002) & Performance; access; security; sensation; information \\
\hline Kaynama and Black (2000) & $\begin{array}{l}\text { Content; accessibility, navigation, design and presentation; } \\
\text { responsiveness; environment; customization }\end{array}$ \\
\hline Kumar-Roy and Balaji (2015) & $\begin{array}{l}\text { Information quality; convenience; functionality; interaction } \\
\text { quality; image quality }\end{array}$ \\
\hline $\begin{array}{l}\text { Parasuraman, Zeithaml, and Malhotra } \\
\text { (2005) }\end{array}$ & $\begin{array}{l}\text { E-S-QUAL: efficiency; system availability; fulfillment; } \\
\text { privacy; E-RecS-QUAL: responsiveness; compensation; } \\
\text { contact }\end{array}$ \\
\hline Sheng and Liu (2010) & Efficiency; fulfillment; system accessibility; privacy \\
\hline Sohail and Shaikh (2008) & Efficiency and security; fulfillment; responsiveness \\
\hline Tsang, Lai, and Law (2010) & $\begin{array}{l}\text { Functionality; information quality and content; fulfillment and } \\
\text { responsiveness; safety and security; appearance and } \\
\text { presentation; customer relationship }\end{array}$ \\
\hline $\begin{array}{l}\text { Vos, Marinagi, Trivellas, Skourlas and } \\
\text { Giannakopoulos (2014) }\end{array}$ & $\begin{array}{l}\text { Ease of use; customization and assurance; e-scape; } \\
\text { responsiveness }\end{array}$ \\
\hline Wolfinbarger and Gilly (2003) & $\begin{array}{l}\text { Design; fulfillment/reliability; privacy/security; customer } \\
\text { service }\end{array}$ \\
\hline Wu, She, and Chang (2015) & $\begin{array}{l}\text { Reliability; responsiveness; information; security; ease of use; } \\
\text { trust }\end{array}$ \\
\hline Yen and Lu (2008) & Efficiency; privacy; protection; contact; fulfillment \\
\hline
\end{tabular}




\section{DIMENSIONS OF SERVICE QUALITY IN THE SHOPPING ONLINE CONTEXT}

\subsection{Design}

The design of a Website plays an important role in attracting, sustaining and retaining the interest of a customer in a site (Ranganathan and Ganapathy, 2002). Numerous studies in the literature consider the Website design as a dimension of e-service quality (Aladwani and Palvia, 2002; Loiacono, Watson, and Goodhue, 2002; Yoo and Donthu, 2001; Liu, Du, and Tsai, 2009; etc.). The literature review about the key factors of a Website design highlights three important issues: attractiveness, proper fonts and proper colors. Although it has sometimes been regarded as a purely aesthetic element, prior studies have demonstrated the influence of Website design on site revisit intention (Yoo and Donthu, 2001), customer satisfaction (Tsang et al., 2010) and loyalty intentions (Wolfinbarger and Gilly, 2003).

\subsection{Functionality}

Functionality refers to the correct technical functioning of the Website. It is one of the most basic requirements for any kind of Website and its meaning is closely related to the dimensions of the system availability (Parasuraman et al., 2005), or technical adequacy (Aladwani and Palvia, 2002). The five items of functionality that we considered were: always up and available, has valid links, loads quickly, enables us to get on to it quickly and makes it easy and fast to get anywhere on the site. Its impact on online customers' higher-order evaluations pertaining to Websites has also been observed. For example, Tsang et al. (2010) conducted an investigation in the travel online context in which the functionality was found to be the most important dimension in increasing customer satisfaction.

\subsection{Privacy}

Websites are usually collecting and storing large amounts of data concerning their users' activities, user evaluations of online questionnaires or personal data (Tan et al., 2012). As a result, one of the aspects that most concern online consumers is the privacy of personal information (ONTSI, 2015). In our study, privacy refers to the degree to which the customer believes that the site is safe from intrusion and personal information is protected (Parasuraman et al., 2005; p. 219). The privacy of a Website should be reflected through symbols and messages to ensure the security of payment and the customer's personal information not being shared with other companies or Internet sites. As such, there appears to be a high degree of support for privacy as an important eservice quality dimension and it was found to be one of the most significant dimensions in increasing customer satisfaction (Janda et al., 2002). 


\subsection{Reliability}

The evaluation of service delivered quality has been carried out with the dimensions of: fulfillment/reliability (Wolfinbarger and Gilly, 2003), reliability (Yang and Jun, 2002), performance (Janda et al., 2002), fulfillment (Parasuraman et al., 2005), etc. Congruent with these articles, our study considers reliability as an important dimension of e-service quality. Moreover, in the context of online services, the information made available by the Websites is an important component of the service delivered. Therefore, reliability refers to the accuracy of the service delivered by the company, the billing process is correct and the information that appears on the Website is clear, current and complete. The service delivered quality or reliability has been empirically shown to have a strong impact on customer satisfaction and quality, and the second strongest predictor of loyalty intentions and attitude towards the Website (Wolfinbarger and Gilly, 2003).

\subsection{Recovery}

Different dimensions have been proposed in the literature to evaluate this aspect: responsiveness (Zeithaml, Parasuraman, and Malhotra, 2000), customer attention (Wolfinbarger and Gilly, 2003), communication (Cai and Jun, 2003), access (Yang and Jun, 2002), etc. In our study, service recovery refers to the customer's capacity to communicate with the organization and how any problem or doubt that may arise is solved. Thus, the Website should show its street, e-mail, phone or fax numbers, the customer service must be available 24 hours a day/7days a week and the response to the customer's inquiries must be quick and satisfactory. Moreover, this latter measure should only be evaluated by individuals who needed help or the solving of a problem.

\section{PROPOSED MODEL AND HYPOTHESIS DEVELOPMENT}

Our model is based on the service quality-satisfaction-loyalty intention chain (Figure 1). The choice of a model and the hypotheses proposed must be made using a theoretical basis and supported by empirical results (Hair et al., 1999). Previous studies (e.g., Dabholkar, 2000; Cronin et al., 2000) give both theoretical and empirical reasons which justify the service quality $\rightarrow$ satisfaction $\rightarrow$ behavior intentions relationship. In the electronic context, recent research also confirms the mediator effect of satisfaction (Yen and $\mathrm{Lu}, 2008$; Collier and Bienstock, 2006). Other authors suggest that service quality has a direct effect on behavior intentions (e.g., Parasuraman et al., 1988; 1991; Zeithaml et al., 1996). In the electronic services context, this effect is likewise confirmed (Parasuraman et al., 2005; Wolfinbarger and Gilly, 2003). Therefore, we expect that:

Hypothesis 1: the electronic service quality will have a positive effect on the consumer's satisfaction.

Hypothesis 2: the electronic satisfaction will have a positive effect on loyalty intentions. 
Hypothesis 3: the electronic service quality will have positive effect on loyalty intentions.

On the other hand, our study examines whether the type of service encounter has a moderating effect in the above hypothesized relationships. As described above, two different service encounters can take place in the context of Internet: (1) service encounters without incidents during which customers get the service for themselves and without the presence of employees and (2) service encounters with incidents with interpersonal and non-interpersonal interactions. These interpersonal interactions take place when a service failure occurs. Such failures can result in significant costs to the firm, such as lost customers and negative word of mouth (Bitner, Brown, and Meuter, 2000). Customers expect effective recoveries when these failures occur (Bitner, Booms, and Tetreault, 1990). Additionally, satisfaction with complaint handling can improve the evaluation of a service experience (Bitner, Booms, and Tetreault, 1990) and increase customer retention (Holloway and Beatty, 2003). Therefore, we expect that:

Hypothesis 1a: in the service encounter with incidents, the electronic service quality will have a higher positive effect on the consumer's satisfaction than in the service encounter without incidents.

Hypothesis 2a: in the service encounter with incidents, the electronic satisfaction will have a higher positive effect on loyalty intentions than in the service encounter without incidents.

Hypothesis 3a: in the service encounter with incidents, the electronic service quality will have a higher positive effect on loyalty intentions than in the service encounter without incidents.

Figure 1: Proposed Model and hypothesis

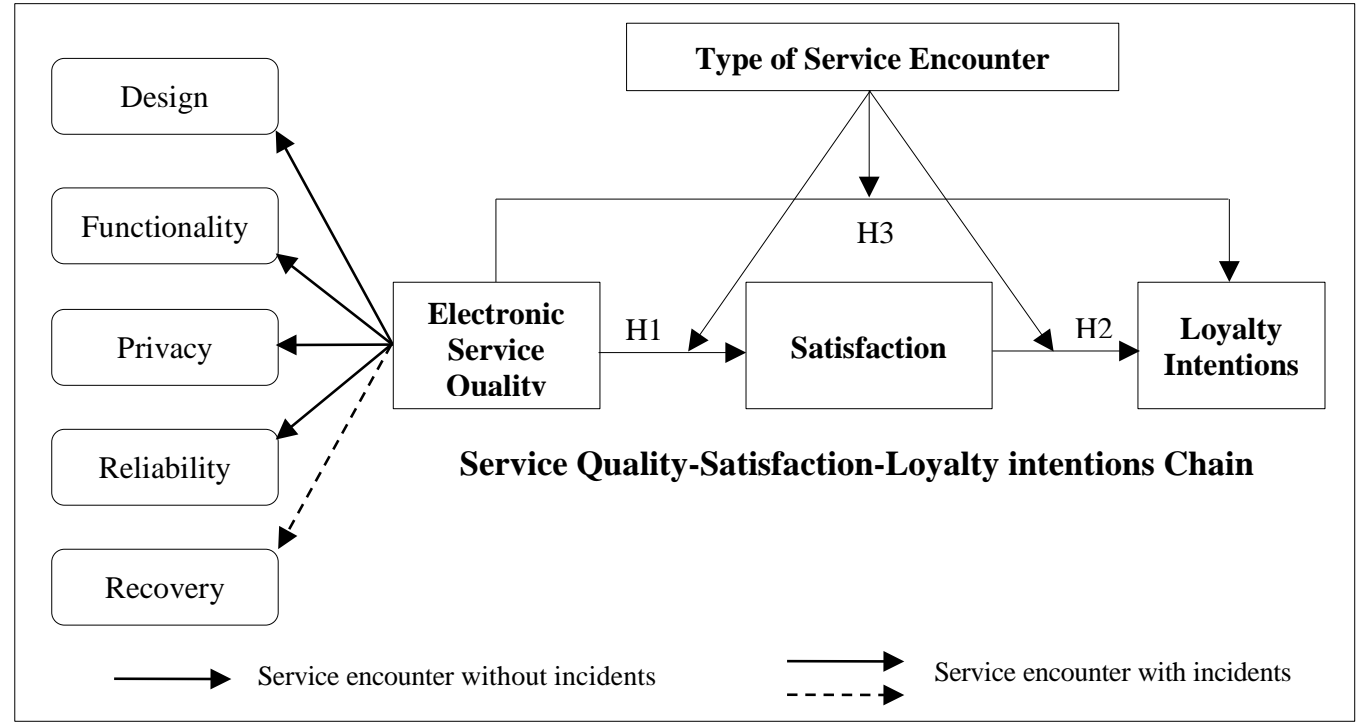




\section{DATA COLLECTION}

Data collection was obtained from a convenience sample of online shoppers. We surveyed purchasers who had already completed online transactions and who had sufficient online shopping experience. The respondents were asked to evaluate a particular Website of their choice, through which they had recently made a purchase. We followed a quota sampling approach, with the intention of reproducing the sociodemographic profile of the population of Spanish online shoppers. The respondents were able to access the Website where the online questionnaire was posted and they received a small incentive for participating. The field work took place from April to June 2012, and 915 questionnaires were received. 718 of them were valid questionnaires and this sample is divided in two groups: 451 participants said that the service delivery was done without any problem (service encounter without incidents) and 267 respondents said that they had a problem or doubt during the online service delivery (service encounter with incidents) (Table 2).

Table 2: Profile of the respondents per service encounter

Service encounter without incidents Service encounter with incidents (451 participants)

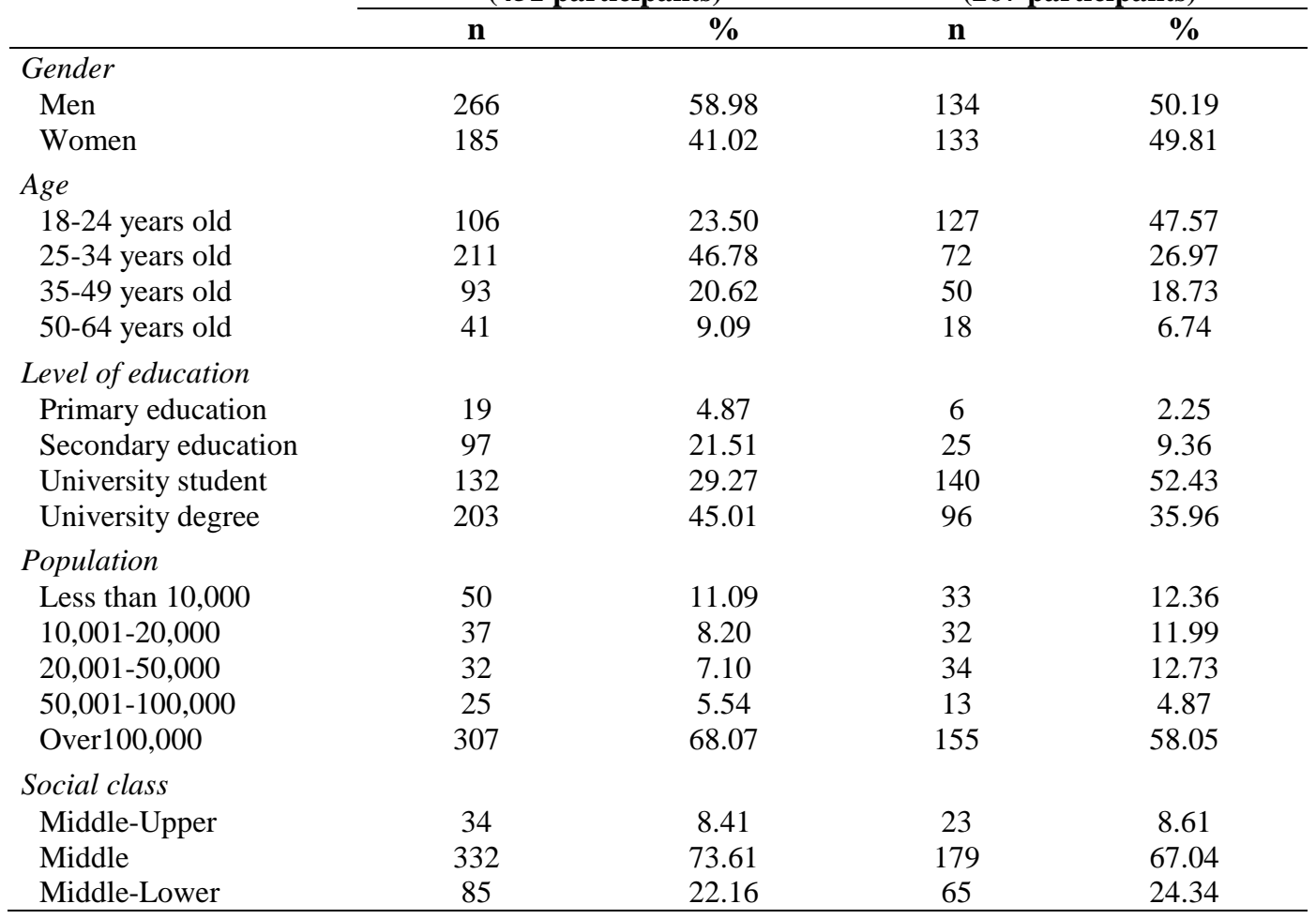


Table 2: Profile of the respondents per service encounter (con't)

\begin{tabular}{lcccc}
\hline \hline & $\begin{array}{r}\text { Service encounter without incidents } \\
\text { (451 participants) }\end{array}$ & $\begin{array}{c}\text { Service encounter with incidents } \\
\text { (267 participants) }\end{array}$ \\
\cline { 2 - 5 } & $\mathbf{n}$ & $\mathbf{\%}$ & $\mathbf{n}$ & $\mathbf{\%}$ \\
\hline $\begin{array}{l}\text { Experience of Internet use } \\
\text { More than 3 years }\end{array}$ & 409 & 90.69 & 255 & 95.51 \\
Between 2 and 3 years & 22 & 4.88 & 7 & 2.62 \\
Less than two years & 20 & 4.43 & 5 & 1.87 \\
Frequency of Internet use & & & & \\
Everyday & 229 & 50.78 & 195 & 73.03 \\
3 to 6 days per week & 151 & 33.48 & 50 & 18.73 \\
One day per week or less & 71 & 15.74 & 22 & 8.24 \\
\hline \hline
\end{tabular}

\section{RESULTS}

\subsection{Assessment of the Measurement Model}

To evaluate the scales proposed, we have followed the traditional procedures used in marketing research (Gerbing and Anderson, 1988). In Table 3 we present the results of dimensionality, convergent validity and reliability assessment. We also offer the standardized loadings, the composite reliability and the average variance extracted (AVE). As can be seen, all the items significantly load in their respective dimensions. The AVE values obtained are all above the recommended value of 0.50 . This indicates that each construct's items have convergent validity. What is more, each construct shows good internal consistency, with reliability coefficients which vary between 0.713 and 0.965 .

With respect to the importance of the e-service quality dimensions, reliability is the most important dimension in the assessment of a Website's service quality, regardless of the type of service encounter. Moreover, in the service encounter with incidents, the second most important aspect of the service quality is how the organization solves the problems or doubts the customers had during the service provision.

Table 3: Dimensionality, Convergent Validity, and Reliability Assessment

Service encounter without incidents Service encounter with incidents

\begin{tabular}{lcccccc}
\hline & \multicolumn{2}{c}{$\begin{array}{c}\text { Service encounter without incidents } \\
\text { (451 participants) }\end{array}$} & \multicolumn{2}{c}{$\begin{array}{c}\text { Service encounter with incidents } \\
\text { (267 participants) }\end{array}$} \\
\cline { 2 - 6 } & SL & CR & AVE & SL & CR & AVE \\
\hline First order factors & & & & & & \\
Design & & 0.775 & 0.535 & & 0.804 & 0.578 \\
DES1 & 0.77 & & & 0.783 & & \\
DES2 & 0.679 & & & 0.732 & & \\
DES3 & 0.743 & & & 0.764 & & 0.690 \\
Functionality & & 0.861 & 0.609 & & 0.899 & \\
$\quad$ FUN1 & 0.689 & & & 0.763 & & \\
\hline
\end{tabular}


Table 3: Dimensionality, Convergent Validity, and Reliability Assessment (con't)

Service encounter without incidents Service encounter with incidents

\begin{tabular}{|c|c|c|c|c|c|c|}
\hline & \multicolumn{3}{|c|}{ (451 participants) } & \multicolumn{3}{|c|}{ (267 participants) } \\
\hline & SL & CR & AVE & SL & CR & AVE \\
\hline FUN2 & 0.764 & & & 0.852 & & \\
\hline FUN3 & 0.818 & & & 0.846 & & \\
\hline FUN4 & 0.842 & & & 0.859 & & \\
\hline FUN5 & Deleted & & & Deleted & & \\
\hline Privacy & & 0.773 & 0.537 & & 0.803 & 0.578 \\
\hline PRI1 & 0.632 & & & 0.699 & & \\
\hline PRI2 & 0.871 & & & 0.859 & & \\
\hline PRI3 & 0.672 & & & 0.712 & & \\
\hline Reliability & & 0.798 & 0.535 & & 0.824 & 0.540 \\
\hline REL1 & 0.751 & & & 0.806 & & \\
\hline REL2 & 0.7 & & & 0.729 & & \\
\hline REL3 & Deleted & & & Deleted & & \\
\hline REL4 & 0.674 & & & 0.701 & & \\
\hline REL5 & 0.694 & & & 0.698 & & \\
\hline Recovery & & - & - & & 0.922 & 0.631 \\
\hline REC1 & - & & & 0.776 & & \\
\hline REC2 & - & & & 0.826 & & \\
\hline REC3 & - & & & 0.823 & & \\
\hline REC4 & - & & & 0.868 & & \\
\hline REC5 & - & & & 0.668 & & \\
\hline REC6 & - & & & 0.768 & & \\
\hline REC7 & - & & & 0.815 & & \\
\hline Satisfaction & & 0.945 & 0.741 & & 0.965 & 0.823 \\
\hline SAT1 & 0.814 & & & 0.88 & & \\
\hline SAT2 & 0.801 & & & 0.912 & & \\
\hline SAT3 & 0.86 & & & 0.924 & & \\
\hline SAT4 & 0.882 & & & 0.905 & & \\
\hline SAT5 & 0.891 & & & 0.909 & & \\
\hline SAT6 & 0.912 & & & 0.911 & & \\
\hline Loyalty intentions & & 0.917 & 0.689 & & 0.945 & 0.775 \\
\hline INT1 & 0.741 & & & 0.842 & & \\
\hline INT2 & 0.754 & & & 0.852 & & \\
\hline INT3 & 0.864 & & & 0.902 & & \\
\hline INT4 & 0.917 & & & 0.919 & & \\
\hline INT5 & 0.859 & & & 0.883 & & \\
\hline Second order factors & & & & & & \\
\hline e-SQ & & 0.777 & 0.567 & & 0.814 & 0.501 \\
\hline e-SQ $\rightarrow$ Design & 0.543 & & & 0.522 & & \\
\hline e-SQ $\rightarrow$ Functionality & 0.617 & & & 0.599 & & \\
\hline e-SQ $\rightarrow$ Privacy & 0.622 & & & 0.608 & & \\
\hline e-SQ $\rightarrow$ Reliability & 0.918 & & & 0.901 & & \\
\hline e-SQ $\rightarrow$ Recovery & - & - & - & 0.755 & & \\
\hline
\end{tabular}

Notes: SL = standardized loadings; CR = Composite Reliability; AVE = Average Variance Extracted; All t-values were greater than $2.576(\mathrm{p}<0.001)$. 
Discriminant validity, which verifies that each factor represents a separate dimension, was analyzed examining whether inter-factor correlations are less than the square root of the average variance extracted (AVE) (Fornell and Larcker, 1981). Table 4 shows that the square roots of each AVE are greater than the off-diagonal elements. With this result, it should therefore be understood that there is discriminant validity in the eservice quality measurement scale.

Table 4: Discriminant validity of measures

\begin{tabular}{ccccccc}
\hline \hline & Design & Functionality & Privacy & Reliability & Satisfaction $\begin{array}{c}\text { Loyalty } \\
\text { intentions }\end{array}$ \\
\hline Design & 0.731 & & & & & \\
Functionality & 0.347 & 0.780 & & & & \\
Privacy & 0.245 & 0.295 & 0.733 & & & \\
Reliability & 0.441 & 0.602 & 0.624 & 0.705 & & \\
Satisfaction & 0.434 & 0.488 & 0.489 & 0.780 & 0.861 & \\
Loyalty intentions & 0.410 & 0.465 & 0.497 & 0.688 & 0.879 & 0.830 \\
\hline \hline
\end{tabular}

Notes: The bold numbers on the diagonal are the square root of the AVE. Off-diagonal elements are correlations between constructs.

\subsection{Assessment of the Structural Model}

As can be seen in Table 5 , the classic service $\rightarrow$ satisfaction $\rightarrow$ loyalty intentions relationship is confirmed in the two contexts. If we look at the structural coefficient value between the service quality and satisfaction with the online shopping, we can see that this coefficient is significant and positive for both types of service encounters. Specifically, when there are problems during the service provision, this coefficient is $0.858(\mathrm{p}<0.001)$, compared to $0.724(\mathrm{p}<0.001)$ in the case of there not having been any incident. Likewise, the relationship between satisfaction and loyalty intentions is greater when the service encounter takes place with incidents (0.745 compared to 0.625; $\mathrm{p}<0.001)$. The direct effect of the service quality on loyalty intentions is $0.184(\mathrm{p}<0.001)$ and $0.132(\mathrm{p}<0.05)$ for the service encounter without and with incidents, respectively. Furthermore, the type of the service encounter has a moderating effect in the service quality-satisfaction-loyalty intentions chain. In these sense, these relationships are stronger for the service encounter with incidents. Therefore, we can accept hypotheses 1, 1a, 2, 2a, 3 and 3a proposed in the theoretical model.

The values of the variance explained for the constructs of satisfaction and loyalty intentions are rather good. To measure the model's fit some indices supplied by the AMOS statistical software were used. Values were recommended close to: 0.95 (CFI), 0.95 (TLI), 0.06 (RMSEA) and 0.08 (SRMR) (Hu and Bentler, 1999). Regarding the RMSEA index, there is also a confidence interval (LO90 and HI90), following the recommendation of Byrne (2009). In both contexts the model has a reasonably good fit of the data. 
Table 5: Structural Models Estimation

\begin{tabular}{lcc}
\hline \hline & $\begin{array}{c}\text { Service encounter without } \\
\text { incidents } \\
\text { (451 participants) }\end{array}$ & $\begin{array}{c}\text { Service encounter with } \\
\text { incidents } \\
\text { (267 participants) }\end{array}$ \\
\hline H1: e-SQ $\rightarrow$ Satisfaction & $0.724^{* * *}$ & $0.858^{* * *}$ \\
H2: Satisfaction $\rightarrow$ Loyalty intentions & $0.629^{* * *}$ & $0.745^{* * *}$ \\
H3: e-SQ $\rightarrow$ Loyalty intentions & $0.184^{* * *}$ & $0.232^{* *}$ \\
Variance explained $\left(R^{2}\right)$ & & \\
Satisfaction & 0.503 & 0.736 \\
Loyalty intentions & 0.597 & 0.784 \\
Fit statistics & & \\
$\chi 2$ & $1,640.498$ & $1,161.254$ \\
Df & 317 & 456 \\
P & 0 & 0 \\
CFI & 0.916 & 0.903 \\
TLI & 0.907 & 0.895 \\
SRMR & 0.062 & 0.053 \\
RMSEA & 0.068 & 0.076 \\
LO90 and HI90 & $0.065-0.072$ & $0.071-0.082$ \\
\hline \hline
\end{tabular}

Notes: ${ }^{* *} \mathrm{p}<0.05 ;{ }^{* * *} \mathrm{p}<0.001 ;$ n.s.: not significant.

\subsection{Comparison of Means}

Next, we carried out the t-Student test and the Mann-Whitney test to analyze if the perceived quality assessment, the customers' satisfaction and their loyalty intentions toward the Website differed according to the type of service encounter (Table 6). The results show that the mean scores of the e-service quality are significantly greater for the service encounter without incidents. Therefore, the consumers who did not have any problem or doubt during the service encounter have a significantly greater valuation of the Website's service quality than those who had an incident during the service provision. Likewise, the satisfaction levels and the loyalty intentions are significantly higher for those consumers who did not have any problem.

Table 6: Student t-test and Mann-Whitney test

\begin{tabular}{|c|c|c|c|c|c|c|c|c|}
\hline & \multirow{2}{*}{$\begin{array}{c}\text { Mean } \\
\text { (Enc. without } \\
\text { incidents) }\end{array}$} & \multirow{2}{*}{$\begin{array}{c}\text { Mean } \\
\text { (Enc. with } \\
\text { incidents) } \\
\end{array}$} & \multicolumn{2}{|c|}{ Levene's Test } & \multicolumn{2}{|c|}{ T-test } & \multicolumn{2}{|c|}{ Mann-Whitney Test } \\
\hline & & & $\mathbf{F}$ & Sig. & $\mathbf{T}$ & $\begin{array}{c}\text { Sig. } \\
\text { (2-tailed) }\end{array}$ & $\mathbf{Z}$ & $\begin{array}{l}\text { Asym. Sig. } \\
\text { (2-tailed) }\end{array}$ \\
\hline e-SQ & & & & & & & & \\
\hline Design & 4.943 & 4.720 & 0.219 & 0.640 & 3.079 & 0.002 & & \\
\hline Functionality & 5.385 & 5.045 & 7.092 & 0.008 & - & - & -3.867 & 0.000 \\
\hline Privacy & 5.065 & 4.707 & 6.967 & 0.008 & - & - & -3.927 & 0.000 \\
\hline Reliability & 5.728 & 5.261 & 20.007 & 0.000 & - & - & -6.072 & 0.000 \\
\hline Satisfaction & 5.906 & 5.249 & 90.557 & 0.000 & - & - & -6.559 & 0.000 \\
\hline Loyalty & 5.424 & 4.919 & 34.484 & 0.000 & - & - & -4.466 & 0.000 \\
\hline
\end{tabular}




\section{CONCLUSIONS AND IMPLICATIONS}

\subsection{Theoretical implications}

In recent years, many researchers have analyzed the components or dimensions that shape the quality of the services offered through Internet. Furthermore, service quality has become the main way to achieve customer satisfaction and, therefore, their loyalty. In our study, the originality of the contribution lies in analyzing these issues in two contexts: service encounters without incidents versus service encounters with incidents. Next, we show the main conclusions of our work.

Firstly, our study confirms that the e-service quality has a direct effect on satisfaction and that the effect of satisfaction on loyalty intentions is important. Moreover, these relationships are statistically significant when the service encounter takes place with or without incidents. Theoretically, the mediator effect of satisfaction on the service quality $\rightarrow$ loyalty intentions relationship is based on the model of Bagozzi (1992), in which the cognitive assessments (service quality) precede emotions (satisfaction with the service), and on the model of Oliver (1977), according to which the cognitive assessment of the service generates an affective or emotional response that leads to behavior or behavior intention. The direct effect of the service quality on loyalty intentions is significant, but not very important. This study therefore up holds that satisfaction partially mediates the effect of the service quality on loyalty intentions. However, this study's first relevant contribution is that there are variables which can moderate these relationships. Specifically, the type of service encounter (with or without incidents) increases or diminishes the strength of these effects. In this sense, when errors occur during the electronic service provision, the measures carried out by the organization to solve these problems are an essential part of the assessment of the service quality provided. Moreover, in these cases, if the customers' problems or doubts are satisfactorily settled, the effects of service quality-satisfaction-loyalty intentions become stronger.

Secondly, regardless of the type of service encounter, reliability is the most important dimension in the assessing of a Website's service quality. When the service encounter takes place with incidents, an important component of the quality of the services offered through a Website is the recovery of the electronic service or how the organization resolves the problems or doubts which have arisen in the service provision. This aspect was the second most important in the assessment of the e-service quality, after the reliability dimension. However, the dimensions related with the technical characteristics of the Website were slighter. Specifically, in spite of there being a strong consensus about the fact that privacy is one of the most important in the evaluation of an online service quality and one of those that have the most influence on customer satisfaction, this research shows the slight importance of this dimension. This fact is possibly due to the technological advances of recent years concerning online purchase payment security 
and there being a growing tendency in the number of customers who are familiar with this type of electronic transactions. A third explanation may be the fact that younger consumers possibly perceive fewer risks in this type of purchases than older consumers (approximately 70\% of our sample's purchasers were between 18 and 34 years old).

Thirdly, in our study we have evaluated the perceived service quality levels (through their dimensions), the levels of satisfaction with the Internet shopping and the loyalty intentions toward the Website where the products or services have been bought. The results show that the consumers who have not had an incident during the service encounter perceive a better service quality, and show greater levels of satisfaction and loyalty intentions toward the Website than the consumers who had a problem during the service provision.

\subsection{Managerial implications}

From the management point of view, firstly, an essential aspect for the success of B2C e-business is for the online suppliers to know which aspects determined the quality of the services offered through Internet. During the first years of e-business, organizations paid more attention to the technical characteristics of the Website: design, functionality, privacy, etc. However, although these aspects are important, the customer's evaluation of the product or service delivery and the way in which their problems or doubts have been resolved during the service provision must not be ignored by any organization. In this vein, the results of this research show that the main aim for any online supplier must be to offer a reliable service for their customers to perceive high quality services and be satisfied. Reliability must be understood as the firm's capacity to fulfill their commitments regarding e-service delivery or provision as agreed in the conditions.

Another very important component of the quality of an e-service is how the consumer perceives that their problems or doubts are resolved by the organization. When mistakes take place during the service provision, the online suppliers must make an effort to solve them or offer the consumer some kind of compensation, given that their satisfaction with the Internet shopping will be greater when no incident occurs and this will therefore increase their loyalty toward the Website. However, our study shows that the performance of the dimensions which make up the e-service quality and the satisfaction and loyalty levels is lower when these incidents exist. These results indicate that organizations often ignore aspects which are subsequent to the online shopping.

\subsection{Limitations and future research lines}

Lastly, some limitations of this work must be recognized and certain future research lines proposed. The convenience samples do not allow the generalizing of the results to the rest of the population. Future studies must be carried out to try and validate and 
generalize the results of this study using a larger sample. And secondly, previous studies have analyzed the effect of e-service quality on the perceived value of online shopping (e.g., Bauer, Falk and Hammerschmidt, 2005; Parasuraman et al., 2005). It would be interesting to analyze how the perceived value is integrated into the service qualitysatisfaction-loyalty intentions chain.

\section{REFERENCES}

Aladwani, A. M., \& Palvia, P. C. (2002). Developing and validating an instrument for measuring user-perceived Web quality. Information and Management, 39(6), 467-476.

Bagozzi, R. P. (1992). The self-regulation of attitudes, intentions and behavior. Social Psychology Quarterly, 55(2), 178-204.

Barrutia, J. M., \& Gilsanz, A. (2012). Electronic service quality and value: Do consumer knowledge-related resources matter. Journal of Service Research, 16(2), 231246.

Bauer, H. H., Hammerschmidt, M., \& Falk, T. (2005). Measuring the quality of ebanking portals. International Journal of Bank Marketing, 23(2), 153-175.

Bitner, M. J. (1990). Evaluating service encounters: The effects of physical surroundings and employee responses. Journal of Marketing, 54(2), 69-82.

Bitner, M. J., Booms, B. H., \& Tetrault, M. S. (1990). The service encounter: Diagnosing favorable and unfavorable incidents. Journal of Marketing, 54(1), 71-84.

Bitner, M. J., Brown, S. W., \& Meuter, M. L. (2000). Technology infusion in service encounters. Journal of the Academy of Marketing Science, 28(1), 138-149.

Byrne, B. (2009). Structural equation modelling with AMOS: Basic concepts, applications, and programming. ( $2^{\text {nd }}$ Ed.). New York: Routledge/Taylor and Francis.

Cai, S., \& Jun, M. (2003). Internet users' perceptions of online service quality: A comparison of online buyers and information searchers. Managing Service Quality, 13(6), 504-519.

Collier, J. E., \& Bienstock, C. C. (2006). Measuring service quality in e-retailing. Journal of Service Research, 8(3), 260-275.

Cronin, J. J., Brady, M. K., \& Hult, G. T. M. (2000). Assessing the effects of quality, value, and customer satisfaction on consumer behavioral intentions in service environments. Journal of Retailing, 76(2), 193-218.

Dabholkar, P. A. (2000). Technology in service delivery: Implications for self-service and service support. In T. A. Swartz \& D. Iacobucci (Eds.), Handbook of Services Marketing (pp. 103-110). New York: Sage.

Duque-Oliva, E. J., \& Rodríguez-Romero, C. A. (2012). Perceived service quality in electronic commerce: An application. Rev. Innovar, 21(42), 89-98. 
Eurostat. (2016). Information Society Statistics. Retrieved June 18, 2015, from http://ec.europa.eu/eurostat.

Fassnacht, M., \& Koese, I. (2006). Quality of electronic services: conceptualizing and testing a hierarchical model. Journal of Service Research, 9(1), 19-37.

Fornell, C., \& Larcker, D. F. (1981). Evaluating structural equation models with unobservable variables and measurement error. Journal of Marketing Research, 18(1), 39-50.

Gerbing, D. W., \& Anderson, J. C. (1988). An updated paradigm for scale development incorporating unidimensionality and its assessment. Journal of Marketing Research, 25(2), 186-192.

Hair, J. F., Anderson, R. E., Tatham, R. R., \& Black, W. C. (1999). Multivariate data analysis. London: Prentice Hall.

Ho, C., \& Lee, Y. (2007). The development of an e-travel service quality scale. Tourism Management, 28(6), 1434-1449.

Hoffman, D. L. \& Novak, T. H. (1996). Marketing in hypermedia computer-mediated environments: Conceptual foundations. Journal of Marketing, 60(3), 50-68.

Holloway, B. B., \& Beatty, S. E. (2003). Service failure in online retailing: A recovery opportunity. Journal of Service Research, 6(1), 92-105.

Hu, L-T., \& Bentler, P. M. (1999). Cutoff criteria for fit indexes in covariance structure analysis: Conventional criteria versus new alternatives. Structural Equation Modeling, 6(1), 1-55.

Janda, S., Trocchia, P. J., \& Gwinner, K. P. (2002). Consumer perceptions of Internet retail service quality. International Journal of Service Industry Management, 13(5), 412-431.

Kaynama, S. A., \& Black, C. I. (2000). A proposal to assess the service quality of online travel agencies: An exploratory study. Journal of Professional Services Marketing, 21(1), 63-88.

Kumar-Roy, S., \& Balaji, M. S. (2015). Measurement and validation of online financial service quality (OFSQ). Marketing Intelligence \& Planning, 33(7), 1004-1026.

Liu, C., \& Arnett, K. P. (2000). Exploring the factors associated with Web site success in the context of electronic commerce. Information and Management, 38(1), 2333.

Liu, C., Du, T. C., \& Tsai, H. (2009). A study of the service quality of general portals. Information and Management, 46(1), 52-56.

Loiacono, E. T., Watson, R. T., \& Goodhue, D. L. (2002). Webqual: A measure of Website quality. American Marketing Association, Winter, 433-437.

Observatorio Nacional de las Telecomunicaciones y de la Sociedad de la Información. (2015). B2C e-commerce Survey. Retrieved Feb 28, 2015, from http://www.red.es/.

Oliver, R. L. (1980). A cognitive model of the antecedents and consequences of satisfaction decisions. Journal of Marketing Research, 17(4), 460-469. 
Oliver, R. L. (1997). Effect of expectations and disconfirmation on post exposure product evaluations. Journal of Applied Psychology, 62(4), 480-486.

Parasuraman, A., Zeithaml, V. A., \& Berry, L. L. (1985). A conceptual model of service quality and its implications for future research. Journal of Marketing, 49(4), 4150.

Parasuraman, A., Zeithaml, V. A., \& Berry, L. L. (1988). SERVQUAL: A multiple-item scale for measuring consumer perceptions of service quality. Journal of Retailing, 64(1), 12-40.

Parasuraman, A., Zeithaml, V. A., \& Berry, L. L. (1991). Understanding customer expectations of service. Sloan Management Review, Spring, 39-48.

Parasuraman, A., Zeithaml, V. A., \& Malhotra, A. (2005). E-S-QUAL. A multiple-item scale for assessing electronic service quality. Journal of Service Research, 7(3), 213-233.

Ranganathan, C., \& Ganapathy, S. (2002). Key dimensions of business-to-consumer Web sites. Information and Management, 39(6), 457-465.

Sabiote, C. M., Frías, D. M., \& Castañeda, J. A. (2012). E-service quality as antecedent to e-satisfaction. The moderating effect of culture. Online Information Review, 36(2), 157-174.

San Martín, S., \& Jiménez, N. H. (2011). Online buying perceptions in Spain: can gender make a difference? Electronic Markets, 21(4), 267-281.

Sánchez-Franco, M. J., \& Villarejo, A. F. (2004). La calidad de servicio electrónico: Un análisis de los efectos moderadores del comportamiento de uso de la Web. Cuadernos de Economía y Dirección de la Empresa, 21, 121-152.

Sheng, T., \& Liu, C. (2010). An empirical study on the effect of e-service quality on online customer satisfaction and loyalty. Nankai Business Review International, 1(3), 273-283.

Shostack, G. L. (1985). Planning the service encounter. In J. A. Czepiel, M. R. Solomon, \& Surprenant, C. F. (Eds.), The Service Encounter. Lexington, MA.: Lexington Books.

Sohail, M. S., \& Shaikh, N. M. (2008). Internet banking and quality of service. Online Information Review, 32(1), 58-72.

Tan, X., Qin, L., Kim, Y., \& Hsu, J. (2012). Impact of privacy concern in social networking web sites. Internet Research, 22(2), 211-233.

Tsang, N. K., Lai, M. T., \& Law, R. (2010). Measuring e-service quality for online travel agencies. Journal of Travel and Tourism Marketing, 27(3), 306-323.

Vos, A., Marinagi, C., Trivellas, P., Skourlas, C., \& Giannakopoulos, G. (2014). Electronic service quality in online shopping and risk reduction strategies. Journal of Systems and Information Technology, 16(3), 170-186.

Wolfinbarger, M., \& Gilly, M. (2001). Shopping online for freedom, control, and fun. California Management Review, 43(2), 34-55.

Wolfinbarger, M., \& Gilly, M. (2003). Etailq: Dimensionalizing, measuring and predicting e-tail quality. Journal of Retailing, 79(3), 183-198. 
Wu, Y. C., She, J. P., \& Chang, C. L. (2015). Electronic service quality of Facebook social commerce and collaborative learning. Computers in Human Behavior, 51(Part B), 1395-1402.

Yang, Z., \& Jun, M. (2002). Consumer perceptions of e-service quality: From Internet purchaser and non-purchaser perspectives. Journal of Business Strategies, 19(1), 19-41.

Yen, C., \& Lu, H. (2008). Effects of e-service quality on loyalty intention: An empirical study in online auction. Managing Service Quality, 18(2), 127-146.

Yoo, B., \& Donthu, N. (2001). Developing a scale to measure the perceived quality of an Internet shopping site (SITEQUAL). Quarterly Journal of Electronic Commerce, 2(1), 31-46.

Zeithaml, V. A., Parasuraman, A., \& Malhotra, A. (2000). A conceptual framework for understanding e-service quality: Implications for future research and managerial practice. Marketing Science Institute Working Paper Report No $01 / 2000$.

Zeithaml, V. A., Parasuraman, A., \& Malhotra, A. (2002). Service quality delivery through Websites: A critical review of extant knowledge. Journal of Academy of Marketing Science, 30(4), 362-375.

Zeithaml, V., Berry, L. L., \& Parasuraman, A. (1996). The behavioral consequences of service quality. Journal of Marketing, 60(2), 31-46.

\section{APPENDIX}

\section{Electronic service quality}

Design

DES1: The Website looks attractive

DIS2: The Website uses fonts properly

DIS3: The Website uses colors properly

Adapted from Liu et al. (2009)

Functionality

FUN1: This Website is always up and available

FUN2: This Website has valid links

FUN3: This Website loads quickly

FUN4: This Website enables me to get on to it quickly

FUN5: This Website makes it easy and fast to get anywhere on the site

Adapted from Aladwani and Palvia (2002), Parasuraman et al. (2005) and Collier and

Bienstock (2006)

Privacy

PRI1: In the Website appear symbols and messages that signal the site is secure

PRI2: The Website assures me that personal information is protected 
PRI3: The Website assures me that personal information will not be shared with other parties

Adapted from Janda et al. (2002), Collier and Bienstock (2006) and Parasuraman et al. (2005)

\section{Reliability}

REL1: The service received was exactly the same as what I ordered

REL2: The billing process was done without mistakes

REL3: Website information is clear

REL4: Website information is current

REL5: Website information is complete

Adapted from Parasuraman et al. (2005), Wolfinbarger and Gilly (2003) and Aladwani and Palvia (2002)

Recovery

REC1: The Website shows its street, e-mail phone or fax numbers

REC2: The Website has customer service representatives

REC3: If I wanted to, I could easily contact a customer service representative

REC4: The Website responds to my inquiries

REC5: The Website gives me a satisfactory response

REC6: When I have a problem the Website shows a sincere interest in solving it REC7: The website responds quickly to my inquiries

Adapted from Collier and Bienstock (2006) and Parasuraman et al. (2005)

\section{Satisfaction}

SAT1: I am satisfied with my decision to purchase from this Website

SAT2: If I had to purchase again, I would feel differently about buying from this Website

SAT3: My choice to purchase from this Website was a wise one

SAT4: I feel good regarding my decision to buy from this Website

SAT5: I think I did the right thing by buying from this Website

SAT6: I am happy that I purchased from this Website

Adapted from Oliver (1980)

\section{Loyalty intentions}

INT1: I consider this Website to be my first choice to buy this kind of services

INT2: I will do more business with the Website in the next few years

INT3: I say positive things about the Website to other people

INT4: I would recommend the Website to someone who seeks my advice

INT5: I encourage friends and relatives to do business with the Website Adapted from Zeithaml et al. (1996)

Notes: All items are measured with a seven-point Likert scale, anchored at 1 "strongly disagree" and 7 "strongly agree". 